\title{
T-Type Calcium Channels: A Potential Novel Target in Melanoma
}

\author{
Carla Barceló ${ }^{1,+}$, Pol Sisó ${ }^{1, \dagger}$, Oscar Maiques ${ }^{2}$, Inés de la Rosa ${ }^{1}$, Rosa M. Martí ${ }^{3,4, \pm ® \text { and }}$ \\ Anna Macià $1, *, \ddagger \mathbb{D}$ \\ 1 Oncologic Pathology Group, University of Lleida, IRBLleida, 25198 Lleida, Spain; \\ carla_barcelo@medicina.udl.cat (C.B.); polsiso95@gmail.com (P.S.); inesrosazurera@gmail.com (I.d.1.R.) \\ 2 Centre for Cancer and Inflammation, Barts Cancer Institute, Queen Mary University of London, \\ London EC1M 6BQ, UK; o.m.carlos@qmul.ac.uk \\ 3 Department of Dermatology, Hospital Universitari Arnau de Vilanova, University of Lleida, IRBLleida, \\ 25198 Lleida, Spain; marti@medicina.udl.cat \\ 4 Centre of Biomedical Research on Cancer (CIBERONC), Instituto de Salud Carlos III (ISCIII), \\ 28029 Madrid, Spain \\ * Correspondence: amacia@irblleida.cat \\ + co-authors. \\ $\ddagger$ co-senior authors.
}

Received: 16 January 2020; Accepted: 6 February 2020; Published: 8 February 2020

\begin{abstract}
T-type calcium channels (TTCCs) are overexpressed in several cancers. In this review, we summarize the recent advances and new insights into TTCC biology, tumor progression, and prognosis biomarker and therapeutic potential in the melanoma field. We describe a novel correlation between the Cav3.1 isoform and the increased basal autophagy in BRAFV600E-mutant melanomas and after acquired resistance to BRAF inhibitors. Indeed, TTCC blockers reduce melanoma cell viability and migration/invasion in vitro and tumor growth in mice xenografts in both BRAF-inhibitor-sensitive and -resistant scenarios. These studies open a new, promising therapeutic approach for disseminated melanoma and improved treatment in BRAFi relapsed melanomas, but further validation and clinical trials are needed for it to become a real therapeutic option.
\end{abstract}

Keywords: T-type calcium channels (TTCCs); melanoma; BRAFV600E; therapy; resistance

\section{Introduction}

Calcium signaling displays important intracellular messages engaging multiple pathways and contributing to cellular homeostasis through calcium ions. Calcium is a second messenger that is involved in physiological functions such as viability, apoptosis, motility, exocytosis and endocytosis, and gene expression, and plays an important role in tumor growth [1-4]. Calcium channels support the entry of calcium in favor of concentration gradients across the plasma membrane into the cell, promoting a calcium influx [5]. These channels can be classified into selective and non-selective calcium channels. Non-selective calcium ion channels are mostly ligand-gated ion channels that open in response to a ligand and mediate cation flux. Additionally, store-operated calcium channels (SOCs) and voltage-gated calcium channels (VGCCs) are considered the two main kinds of selective calcium channels that mediate calcium influx in response to the depletion of intracellular calcium stores [6].

VGCCs are the most selective channels for calcium ions. VGCCs are heteromultimers assembled by a main $\alpha 1$-subunit and three auxiliary subunits, $\alpha 2-\delta, \beta$, and $\gamma$, which regulate the expression and biophysical properties of the channels [7]. The $\alpha 1$-subunit is the largest one (190-250 kDa) contributing to the pore architecture and potential change sensor, in addition to being the main channel regulator, which determines the type of VGCC [8,9]. The $\alpha 1$-subunit of VGCCs is composed of four domains, 
which have six transmembrane segments (S1-S6) each [10]. The $\beta$ subunits ( $\beta 1-4)$ are cytosolic proteins that regulate current density, control channel activation/inactivation kinetics, and shift the voltage dependence and activation in the hyperpolarized direction. On the other side, the $\gamma$ subunits $(\gamma 1-8)$ can have an inhibitory effect on calcium currents and can alter the activation/inactivation kinetics of the calcium channels [7,11-14].

VGCCs are activated and inactivated by plasma membrane depolarization and can be classified into three different families based on sequence homology and functional properties: (1) high-voltage-activated L-type channels (Cav1), (2) high-voltage-activated P/Q-type, N-type, and R-type channels (Cav2), and (3) low-voltage-activated T-type channels (Cav3). Three different genes that encode T-type calcium channels (TTCCs) have been described, including CACNA1G, CACNA1H, and CACNA1I, which encode for the main $\alpha$-pore forming subunits Cav3.1, Cav3.2, and Cav3.3, respectively [15]. The diverse isoforms are differentiating due to their electrophysiological and pharmacological properties (Table 1). TTCCs are the only calcium low-voltage channels described to date, due to the fact that they require small depolarization to open. Further, they have a window current, as they can open but not inactivate completely, resulting in significant calcium entry at membrane potentials near rest $[8,16,17]$.

Table 1. T-type calcium channel (TTCC) expression and cellular function in melanoma. ND: not determined.

\begin{tabular}{|c|c|c|c|}
\hline Cellular Functions of TTCCs & Cav3.1 & Cav3.2 & Cav3.3 \\
\hline Molecular Information & Human: 2377aa, O43497, chr. 17q22, CACNA1G & $\begin{array}{l}\text { Human: 2353aa, O95180, chr. 16p13.3, } \\
\text { CACNA1H }\end{array}$ & $\begin{array}{l}\text { Human: 2251aa, AAM67414, chr. } \\
\text { 22q13.1, CACNA1I }\end{array}$ \\
\hline Threshold mV & -70 & -70 & -70 \\
\hline mRNA & + & + & + \\
\hline Protein & $\mathrm{IHC}$ & $\mathrm{IHC}$ & ND \\
\hline Functional Channels & + & + & + \\
\hline Prognosis in Melanoma & Negative & Negative & ND \\
\hline \multirow{9}{*}{ Expression Levels } & $\begin{array}{l}\uparrow \text { mRNA expression in melanoma cell lines and } \\
\text { biopsies compared with melanocytes [18] }\end{array}$ & $\begin{array}{l}\uparrow \text { mRNA expression in melanoma cell lines } \\
\text { and biopsies compared with melanocytes } \\
{[18]}\end{array}$ & $\begin{array}{c}\uparrow \text { mRNA expression in melanoma cell } \\
\text { lines and biopsies compared with } \\
\text { melanocytes [18] }\end{array}$ \\
\hline & Hypoxia $\uparrow$ mRNA expression (M16, JG, M28) [19] & Hypoxia $\uparrow$ mRNA expression [19] & $\begin{array}{l}\uparrow \text { mRNA expression in BRAFV600E } \\
\text { melanoma [20] }\end{array}$ \\
\hline & $\begin{array}{l}\uparrow \text { immunoexpression from normal skin to naevi } \\
\text { to melanoma biopsies (tumor progression) [21] }\end{array}$ & $\begin{array}{l}\uparrow \text { immunoexpression from normal skin to } \\
\text { naevi to melanoma biopsies (tumor } \\
\text { progression) [21] }\end{array}$ & \\
\hline & $\begin{array}{l}\uparrow \text { immunoexpression in primary melanoma } \\
\text { tumors with Breslow thickness }>1 \mathrm{~mm}[21]\end{array}$ & $\begin{array}{l}\uparrow \text { immunoexpression in primary melanoma } \\
\text { tumors with Breslow thickness }>1 \mathrm{~mm} \text { [21] }\end{array}$ & \\
\hline & $\begin{array}{l}\uparrow \text { immunoexpression positively correlates with } \\
\text { BRAFV600E protein expression and LC3 [21] }\end{array}$ & $\begin{array}{c}\uparrow \text { immunoexpression positively correlates } \\
\text { with Glut1 and Ki-67 [21] }\end{array}$ & \\
\hline & $\begin{array}{l}\uparrow \mathrm{mRNA} \text { expression and immunoexpression in } \\
\text { BRAFV600E melanoma [20] }\end{array}$ & & \\
\hline & $\begin{array}{c}\uparrow \text { mRNA expression and immunoexpression in } \\
\text { BRAF inhibitor-resistant melanoma [22] }\end{array}$ & & \\
\hline & $\begin{array}{l}\uparrow \text { mRNA expression during acquisition of } \\
\text { Vemurafenib resistance in melanoma [22] }\end{array}$ & & \\
\hline & $\begin{array}{c}\downarrow \text { mRNA expression after TTCC blocker } \\
\text { treatment in sensitive and Vemurafenib-resistant } \\
\text { melanoma [22] }\end{array}$ & & \\
\hline \multirow{4}{*}{ Cellular function } & $\begin{array}{l}\text { TTCC blocker or molecular knockdown of Cav3.1 } \\
\text { expression arrest cells in G1 phase and decreases } \\
\text { cell viability in melanoma cells }[18,19,22]\end{array}$ & $\begin{array}{l}\text { TTCC blocker or molecular knockdown of } \\
\text { Cav3.2 expression arrest cells in G1 phase } \\
\text { and decreases cell viability in melanoma } \\
\text { cells }[18,19,22]\end{array}$ & $\begin{array}{l}\text { TTCC blocker arrests cells in G1 phase } \\
\text { and decreases cell viability in } \\
\text { melanoma cells }[18,19,22]\end{array}$ \\
\hline & $\begin{array}{l}\text { TTCC blocker or molecular knockdown of Cav3.1 } \\
\text { expression impairs migration/invasion rates in } \\
\text { BRAFV600E-mutant melanoma cells [20] }\end{array}$ & $\begin{array}{l}\text { TTCC blocker or molecular knockdown of } \\
\text { Cav3.2 expression impairs } \\
\text { migration/invasion rates in } \\
\text { BRAFV600E-mutant melanoma cells [20] }\end{array}$ & $\begin{array}{c}\text { TTCC blocker impairs } \\
\text { migration/invasion rates in } \\
\text { BRAFV600E-mutant melanoma cells } \\
{[20]}\end{array}$ \\
\hline & TTCC blocker reduces tumor growth in vivo [5] & $\begin{array}{l}\text { TTCC blocker reduces cell viability and } \\
\text { inhibit migration/invasion rates in } \\
\text { Vemurafenib-resistant melanoma cells [20] }\end{array}$ & $\begin{array}{c}\text { TTCC blocker reduces cell viability } \\
\text { and inhibit migration/invasion rates in } \\
\text { Vemurafenib-resistant melanoma cells } \\
{[20]}\end{array}$ \\
\hline & $\begin{array}{l}\text { TTCC blocker reduce cell viability and inhibit } \\
\text { migration/invasion rates in Vemurafenib-resistant } \\
\text { melanoma cells [20] }\end{array}$ & $\begin{array}{l}\text { TTCC blocker reduce tumor growth } \\
\text { in vivo [22] }\end{array}$ & $\begin{array}{l}\text { TTCC blocker reduce tumor growth } \\
\text { in vivo [22] }\end{array}$ \\
\hline \multirow{2}{*}{ Relative to Autophagy } & $\begin{array}{l}\text { TTCC blocker or molecular knockdown of Cav3.1 } \\
\text { blocks autophagy flux in all melanoma cells } \\
\qquad[19,20,22]\end{array}$ & $\begin{array}{l}\text { TTCC blocker or molecular knockdown of } \\
\text { Cav3.2 blocks autophagy flux in all } \\
\text { melanoma cells }[19,20,22]\end{array}$ & $\begin{array}{l}\text { TTCC blockade inhibits autophagy } \\
\text { flux in all melanoma cells }[19,20,22]\end{array}$ \\
\hline & $\begin{array}{l}\text { TTCC blocker inhibit autophagy flux in } \\
\text { Vemurafenib-resistant melanoma cells [22] }\end{array}$ & $\begin{array}{l}\text { TTCC blocker inhibit autophagy flux in } \\
\text { Vemurafenib-resistant melanoma cells [22] }\end{array}$ & $\begin{array}{l}\text { TTCC blocker inhibit autophagy flux } \\
\text { in Vemurafenib-resistant melanoma } \\
\text { cells [22] }\end{array}$ \\
\hline
\end{tabular}




\section{T-Type Calcium Cannels in Cancer}

VGCCs have been reported as promising candidates in targeted-cancer therapy [23]. Among VGCCs, TTCC s have been suggested as potential targets because of their upregulation in diverse tumor cells. Indeed, they are involved into the progression and prognosis of various cancers $[14,24,25]$.

To date, it has been suggested that TTCC expression and isoforms are heterogeneous, depending on the stage of tumor development and cancer type. TTCCs, the Cav3.1 and Cav3.2 isoforms in particular, have been found to be overexpressed in prostate [26,27], breast [28-30], ovarian [31,32], colon [33] and esophageal [34] cancers, retinoblastoma [29], glioblastoma [35], hepatocellular carcinoma [36], and melanoma [18]. The Cav3.3 isoform has been reported to be increased in ovarian and esophageal cancer, hepatocellular carcinoma, and melanoma [14]. Consequently, the pharmacological inhibition of channels function or the molecular knockdown of TTCC expression is able to decrease proliferation and cell viability and increase apoptosis and arrest cells in the G1 phase in specific cancer types [14].

In silico data also supports this hypothesis. For instance, a microarray database (Oncomine) and bioinformatic analysis, performed by Phan and colleagues, indicated that both the up- and downregulation of TTCCs could be involved in a cancer's molecular signature [23]. Such a study supports the complexity of calcium signaling, which needs further investigation in order to strongly associate VGCC expression within cancer progression. In addition, the aberrant hypermethylation of the CACNA1G gene (Cav3.1) can modulate TTCC expression. It has been found in various human primary tumors (colorectal, pancreatic, hepatic, and gastric cancer, as well as in acute myeloid leukemia), causing a drastic reduction in Cav3.1 levels. The inactivation of CACNA1G in particular neoplasms suggests that it may play a role as a tumor suppressor gene in such tumors [37-40].

\section{Expression of T-type Calcium Channels in Melanoma}

Cutaneous melanoma is a malignant skin cancer that arises from transformed melanocytes de novo or from congenital or acquired melanocytic nevi [41]. Melanoma is the most dangerous form of skin cancer, and its incidence is steadily increasing worldwide. Since melanoma can be diagnosed in young and middle-aged adults [42,43], it causes unbalanced mortality in that population, being responsible of one of the highest rates of loss of potential life for adult-onset cancers [44]. Melanoma cells have a high ability of local invasion and metastasis, even when arising from very small-volume tumors [45]. Once in advanced stages, the prognosis of melanoma is still poor, despite being the subject of intense research groups and numerous clinical trials that have increased therapeutic options, such as certain targeted and immunotherapies [46].

Available evidence indicates that calcium signaling plays an important role in melanoma cell viability and motility $[47,48]$. In 2012, it was reported for the first time that TTCCs were highly expressed in melanoma cells compared with melanocytes. Likewise, it was shown that TTCC expression was functional using calcium imaging techniques, which measure changes in the concentration of intracellular calcium flux through the membrane-permeable fluorescent dye Fura-2, which has the ability to bind to calcium [18].

Afterwards, using human biopsies, Maiques and colleagues were able to study the expression of TTCCs, comparing normal skin, melanocytic nevi, and melanoma tumors, with the aim of establishing a correlation between tumor progression and disease-free survival. By immunohistochemistry techniques, they described a progressive increase in the expression of TTCCs from normal skin to common nevi, dysplastic nevi, and primary and metastatic melanoma samples, but with differences in the distribution of TTCC isoforms (Table 1; Figure 1A). Particularly, Cav3.2 expression was significantly higher in metastatic melanoma than in primary melanoma, while Cav3.1 expression was increased in all samples of melanoma (both primary and metastatic). Moreover, a positive correlation was indicated between Breslow thickness-an important clinicopathological prognostic factor in primary melanomas-and the expression of TTCCs (Cav3.1 and Cav3.2) (Figure 1A) [21]. Additionally, the same study analyzed the presence of Cav3.1 and Cav3.2 isoforms in the four main primary cutaneous melanoma subtypes (superficial spreading malignant melanoma (SSMM), nodular melanoma (NM), acral lentiginous 
melanoma (ALM), and lentigo maligna melanoma (LMM)). Whilst the expression of Cav3.1 was not significantly different between the primary melanoma subtypes, the expression of Cav3.2 was higher in NM and ALM, suggesting a possible contribution of Breslow thickness [21].

A

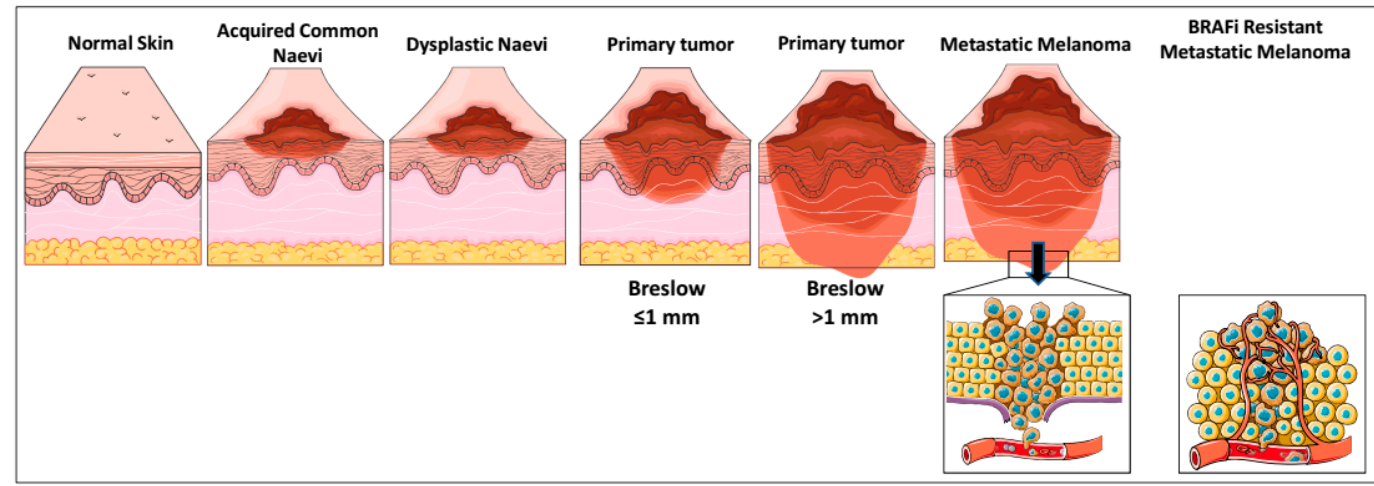

Immunoexpression and mRNA levels of Cav3.1
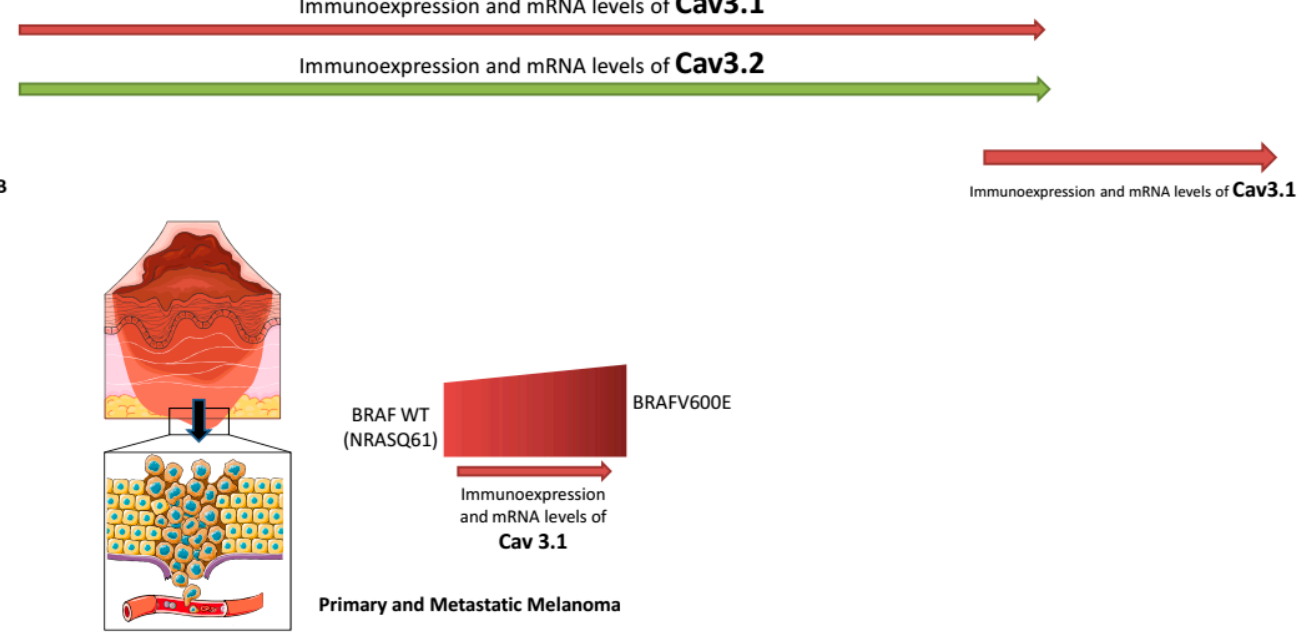

Figure 1. Cav3.1 and Cav3.2 T-type calcium channel (TTCC) expression during the progression of melanoma and depending on genetic profile. (A) Increased expression of Cav3.1 and Cav3.2 during melanoma progression (Clark model) and after acquisition of resistance to BRAF inhibitors (the last in the case of BRAF ${ }^{\mathrm{V} 600 \mathrm{E}}$ melanoma). (B) Expression of Cav3.1 in primary and metastatic melanoma depending on genetic profile (BRAF ${ }^{\mathrm{V} 600 \mathrm{E}}$ vs. non-BRAF-mutant melanoma).

It is well known that the most prevalent genetic hallmark of cutaneous melanoma is the presence of BRAF (BRAFV600E/K, 40-50\%) or NRAS (NRASQ61, 20\%) mutations, which are mutually exclusive [49]. Recently, the expression of TTCCs was investigated in different melanoma cell lines and human biopsies according to their genetic profile [20]. Melanoma cell lines that harbored BRAFV600E mutation showed higher mRNA levels of the Cav3.1 and Cav3.3 isoforms compared with melanoma cells with NRAS mutation, whereas no significant differences were observed regarding Cav3.2 mRNA levels. Extending it to clinical settings, a cohort of primary and metastatic melanoma human biopsies bearing BRAF $\mathrm{V} 600 \mathrm{E} / \mathrm{K}$ gene mutation showed a higher immunoexpression of Cav3.1 compared with a BRAF wild-type melanoma cohort (Table 1; Figure 1B) [20].

\section{The Role of T-Type Calcium Channels in Melanoma}

The concentration and tight regulation of calcium is essential for the communication of the extracellular medium, with different cellular compartments involved in calcium homeostasis during processes such as cell cycle, proliferation, apoptosis, and migration. TTCCs can regulate a variety of 
calcium-dependent cellular processes to support malignant growth, including proliferation, motility, survival, and differentiation.

\subsection{Cell Proliferation and Apoptosis}

Cell proliferation is a complex mechanism orchestrated by several proteins and might be regulated by calcium signaling in different parts of the cell. TTCCs seem to be especially suitable for promoting cell cycle progression due to its rapid activation after weak depolarization. This feature allows for transient increases in cytosolic calcium in non-excitable cells that seem to favor mitotic progression by the direct binding of calcium to intracellular effectors such as calmodulin (CaM). VGCCs also participate in the progression of cancer by generating calcium wave oscillations, such as those provided by TTCCs, which favor the progression of the cell cycle [3]. Initial results showed that TTCC expression plays a crucial role in melanoma cell viability and in the induction of cell cycle progression (Figure 2). TTCC knockdown experiments of Cav3.1 and Cav3.2 genes have induced cell cycle arrest at the G1 and $\mathrm{S}$ phases. Specifically, the Cav3.1 isoform has been associated with slow cycling and upregulation under environmentally stressful conditions, such as hypoxia. It has also been shown that Cav3.2 expression correlates with high proliferation rates in melanoma cells [18]. In the same way, by immunodetection of different proteins involved in the progression and development of melanoma, it was determined that the Cav3.2 isoform was associated with Glut1 expression-a marker of hypoxia-as well as with cyclin D1 and Ki-67-two markers of proliferation [21].

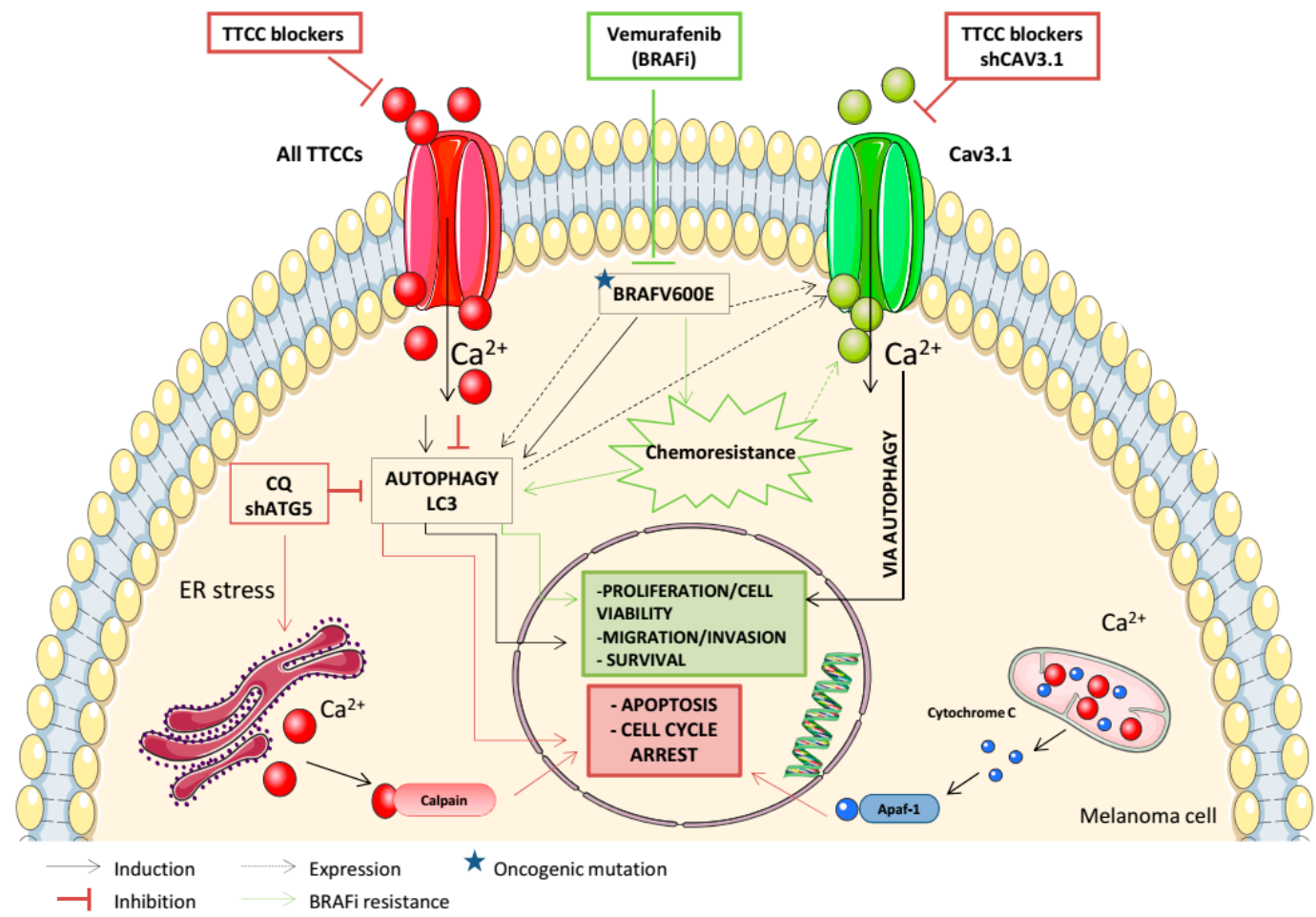

Figure 2. TTCCs play a significant role in cellular proliferation, apoptosis, migration, autophagy, and acquisition of BRAFi resistance in melanoma. The figure represents the relationships identified in different studies between TTCC expression and autophagy, and the effects of TTCC blockers in melanoma cells.

Consequently, the inhibition of TTCCs affects their functionality; therefore, the cellular functions involved are compromised. Mibefradil was the first selective pharmacological TTCC inhibitor approved by the FDA; it was marketed by Roche as Posicor ${ }^{\circledR}$ for the treatment of hypertension, but was later withdrawn due to drug-drug interactions [50]. However, Mibefradil has been recently re-approved, under the condition of "orphan medication," so that its efficacy for the treatment of pancreatic 
cancer, glioblastoma multiforme, and ovarian cancer can be investigated (clinicaltrials.gov). Similarly, Pimozide-an antipsychotic drug-is also a strong inhibitor of TTCCs that inhibits tumor cell proliferation and decreases cell migration in hepatocellular carcinoma [51], prostate cancer [52], breast cancer [53], and melanoma [54].

In a follow-up study, Das and colleagues showed that TTCC blockers of clinical use (Mibefradil and Pimozide) had a dual effect on cell viability. They clearly decreased BrdU incorporation in melanoma cells compared with untreated cells, and a halt in cell proliferation was indicated, but a remarkable increase in apoptotic cell death was also observed (an increase in propidium iodide (PI) staining cells and the percentage of cells in the sub-G1 phase) (Figure 2). Further, it was determined that the apoptotic death of melanoma cells was partially dependent on caspase cascade activation, through the appearance of a cleavage fragment of effector caspase-3 after TTCC blocker treatment [19]. An in-depth analysis of the death process induced by TTCC blockers revealed that the apoptotic pathway was preceded by endoplasmic reticulum (ER) stress and the subsequent inhibition of basal macroautophagy, which is constitutively active in melanoma cells (Table 1) $[19,21,55,56]$. TTCCs have been suggested to couple the calcium influx to ER calcium storage [57]. It has been shown that TTCC blockers induce ER stress with an upregulation of unfolded protein response (UPR) markers (chaperone GRP78, transcription factor XBP-1, and GADD153) as an anti-tumoral strategy in melanoma cells [19].

\subsection{Autophagy}

Autophagy is a catabolic process that helps to maintain cellular homeostasis, so that cells can degrade and recycle damaged organelles and proteins through catabolism [58]. The crosstalk between calcium and autophagy has a central role in cellular homeostasis and survival during several physiologic and pathologic conditions [59]. Autophagy is constitutively induced in melanoma cells and is a housekeeping process involved in tumor progression and melanoma metastasis $[19,56,60,61]$.

Our group was the first to show that the Cav3.1 isoform is upregulated in both melanoma cell lines and biopsies from BRAF ${ }^{\mathrm{V} 600 \mathrm{E}}$-mutant melanomas, which was accompanied by increased levels of LC3II protein-important for the autophagic process-compared with NRAS-mutant melanomas [20]. In line with this, we described a significant correlation between the presence of BRAFV600E - mutant protein with Cav3.1 expression and a positive link to LC3II protein in a cohort of primary and metastatic melanomas (Table 1; Figure 2) [21]. These results reinforce the basal autophagy present in melanoma, which is enhanced in $\mathrm{BRAF}^{\mathrm{V} 600 \mathrm{E}}$-mutant melanoma cells and related to the upregulation of the Cav3.1 isoform.

TTCC blockers inhibit autophagy and induce cell death in all melanoma cells, regardless of the specific mutation present $[19,20]$. Recently, our group performed in vivo xenograft mouse models with subcutaneous injections of melanoma cell lines, with a further administration of Mibefradil daily via oral gavage for $2 \mathrm{w}$. We showed that TTCC blocker treatment significantly reduces tumor growth and induces apoptosis via an autophagy blockade in xenograft melanoma models (Table 1) [22].

Mitophagy is an essential process that maintains mitochondrial quality and number, thus limiting cellular degeneration. Along with apoptosis, mitophagy participates in cellular fate decisions by eliminating damaged mitochondria. A variety of mitochondrial parameters (structure, membrane potential, own machinery, etc.) are important regulators of the mitochondrial capacity for calcium uptake due to their close apposition with the ER [62]. Mitochondrial calcium is rapidly balanced by an equivalent calcium outflow from the organelle, which depends on the exchange of sodium, but only up to a cytosolic concentration called the "mitochondrial set point." TTCCs have to satisfy both the maintenance of a sustained influx of calcium into the cell and the direct part of this calcium towards the mitochondria. Gouriou and colleagues have shown that cytosolic calcium elevations were paralleled by mitochondrial calcium elevations, which were also increased by TTCCs overexpression [63].

Autophagy-mediated degradation of ER fragments or ER-phagy contributes to the removal of aberrant protein products from the lumen or ER membrane. The ER acts as a dynamic intracellular calcium reservoir, controlling cytosolic calcium levels [64]. It has been shown that disruptions in the 
cellular energy levels, the redox state, or calcium concentrations reduce the protein folding capacity of the ER, and lead to the accumulation and aggregation of unfolded proteins, resulting in ER stress [65].

\subsection{Migration and Invasion}

Cell migration is a process whereby cancer cells escape the primary tumor and invade other tissues to develop metastases. Maiques and co-workers assessed the effect of TTCC blockers on the migration and invasion of melanoma cells using wound-healing, single-cell, and transwell assays [66]. We showed that TTCC blockers reduce the migration rates and invasive potential of $\mathrm{BRAF}^{\mathrm{V} 600 \mathrm{E}}$-mutant melanoma cells due to autophagy inhibition, with no significant effect in NRAS-mutant melanoma cells (Table 1; Figure 2) [20,66]. Melanoma cell invasion and subsequent metastasis are hallmarks of melanoma dissemination [67]. Snail1 is a transcription factor that induces epithelial-mesenchymal transition (EMT) [68], and it has been shown to be crucial during melanoma cell motility and invasiveness $[20,69,70]$. Moreover, Snail1 expression was higher in $\mathrm{BRAF}^{\mathrm{V} 600 \mathrm{E}}$-mutant melanomas compared with BRAF wild-type melanoma cells and biopsies, and its expression decreases upon an autophagy blockade by TTCC blockers. Consequently, we stated that Snail1 could be essential during a metastatic cascade of melanomas with BRAF mutation [20]. All the effects produced by pharmacological blockers of TTCCs related with the induction of apoptosis, the blockade of autophagy, and the reduction of migration/invasion processes in melanoma cells were mimicked by TTCC gene silencing (Figure 2) [19,20].

\subsection{Tumor Progression and Prognostic Marker}

Several studies emphasize the expression of TTCCs not only as a marker of tumor progression, but also as a prognostic marker. Indeed, in silico analysis of the database from The Cancer Genome Atlas (TCGA) indicated that disease-free survival (DFS) and overall survival (OS) were inversely correlated with the increased expression of Cav3.2, and DFS was also inversely correlated with overexpression of Cav3.1 (Figure 2). All results indicate that the expression of these two TTCC isoforms correlates with the tumor progression of melanoma and that their overexpression in the primary tumor may be an indicator of poor prognosis [21].

\section{T-Type Calcium Channels and BRAF Inhibitor Resistance in Melanoma}

A high frequency of activation of several mechanisms in cancer cells underlying the development of resistance under pharmacological treatment (chemotherapy, target therapy or immunotherapeutic agents) has been widely described. As mentioned, a high percentage of melanoma cases (40-60\%) present $\mathrm{BRAF}^{\mathrm{V} 600}$ mutation (V600E or $\mathrm{V} 600 \mathrm{~K}$ ) [71]. Vemurafenib was the first $\mathrm{BRAF}^{\mathrm{V} 600 \mathrm{E}}$ drug inhibitor (BRAFi) approved for the treatment of advanced melanoma. However, progressive disease after a short period of administration was one of the main issues (common to other BRAF inhibitors, such as Dabrafenib), leading to the development of secondary resistance [72]. A number of molecular mechanisms underlying this resistant phenotype have already been elucidated, by reactivation of the MAPK and/or the PI3K-Akt pathways [73-76]. Therefore, a deeper characterization of resistance mechanisms to BRAFi remains essential for determining new-generation therapeutic strategies [77-79].

An increasing number of studies have shown a clear link between calcium channel expression and sensitivity to therapeutic drugs. Many calcium channels are involved in quimioresistance acquisition in a large variety of cancers [80]. To date, in addition to our group results, there are no studies about TTCCs and melanoma treatment resistance acquisition. Our team is the first to propose that overexpression of TTCC Cav3.1 could be a key mechanism in the acquisition of BRAFi resistance in melanoma cells. In this context, we set out to study the modulation of TTCCs and/or the inhibition of autophagy as a possible therapy for Vemurafenib-resistant melanoma. In fact, our group recently demonstrated that chronic exposure to Vemurafenib-induced drug resistance in $\mathrm{BRAF}^{\mathrm{V} 600 \mathrm{E}}$-mutant melanoma cells was due to a Vemurafenib-promoting autophagic process, a mechanism that contributes to BRAFi resistance in melanoma cells [22,81-83]. In addition, Barceló and colleagues showed that 
both Vemurafenib-resistant $\mathrm{BRAF}^{\mathrm{V} 600 \mathrm{E}}$-mutant melanoma cells and biopsies from human melanoma relapsing under BRAFi expressed higher levels of the Cav3.1 isoform and the LC3 protein compared with their parental Vemurafenib-sensitive cell line or pre-treatment melanoma tumors, respectively (Table 1; Figures $1 \mathrm{~A}$ and 2). In silico analysis reinforced this observation, indicating that Cav3.1 enrichment and enhanced basal autophagy influence the arising intrinsic mechanism of BRAFi resistance in melanoma. Furthermore, in the same study, we determined that a TTCC blocker (Mibefradil) decreases cell viability and induces apoptosis as well as impairs migration and invasion rates in Vemurafenib-resistant melanoma cells due to autophagy inhibition (Table 1; Figure 2). In addition, oral administration of Mibefradil in SCID mice models reduced tumor growth in resistant melanoma cells and induced apoptosis via a blockade of autophagy [22]. These results suggest that the inhibition of autophagy, induced indirectly through TTCC blockers, could be a therapeutic tool to drive apoptosis and to reduce migration and invasion rates in BRAFi melanoma-resistant cells. It therefore could be a new therapy against the secondary resistance of melanoma arising after chronic treatment with Vemurafenib.

\section{T-type Calcium Channels as a Therapeutic Target in Melanoma}

Identifying TTCC expression in tumors and characterizing their functionality may introduce alternative treatments, particularly for patients in which the tumor relapses after standard therapies.

At present, it is possible to arrest cancer cell proliferation and induce cell death by inhibiting TTCCs on a wide range of cancer cells. Conversely, the use of TTCC pharmacological blockers has proven effective in reducing the viability of tumor cells grown in vitro $[19,20,22,30,31,84]$ and in preclinical tumor growth mice models $[22,30,31,85,86]$. There are a variety of agents that could affect TTCCs with varying degrees of specificity. As mentioned, the TTCC blocker, Mibefradil, is an FDA "orphan drug" approved for its efficacy to treat ovarian cancer (2007), pancreatic cancer (2008), and glioblastoma multiforme (2009) (https://www.accessdata.fda.gov/scripts/opdlisting/oopd/listResult.cfm). Mibefradil has been recognized as a proliferative inhibitor in many different cell lines, including mononuclear blood cells [87], leukemia [88], glioblastoma [89], retinoblastoma [90], and tumor cells of the pituitary gland [91]. Apart from its anti-proliferative properties, Mibefradil has been shown to affect cell motility and the invasive properties of fibrosarcoma [92].

Melanomas are highly heterogeneous due to their mutational and epigenetic profiles and, when disseminated, poorly respond to chemotherapy and radiotherapy regimens, so diverse specific targets involved in melanoma progression are under evaluation. Therefore, the development of innovative strategies remains critical for increasing available anticancer therapies for melanoma. A number of publications reporting TTCC expression (especially Cav3.1 and Cav3.2) in melanoma are now available. These describe the involvement of TTCCs in melanoma progression and as a prognostic biomarker, Cav3.1 upregulation in $\mathrm{BRAF}^{\mathrm{V} 600 \mathrm{E}}$-mutant melanomas, and further involvement in the acquisition of resistant mechanisms to conventional treatments (Figure 2) [19-22]. It has been shown that pharmacological inhibitors of TTCCs induce a cell cycle arrest, induce a caspase-dependent apoptosis, and reduce tumor growth preceded by the activation of ER stress and the subsequent inhibition of the autophagic flux, constitutively activated in melanoma cells [19,22]. Indeed, Mibefradil treatment induces cell death and reduces the migration/invasion rates in $\mathrm{BRAF}^{\mathrm{V} 600 \mathrm{E}}$-mutant melanoma cells due to autophagy blockade, as a possible emerging therapeutic strategy against melanoma progression (Table 1; Figure 2) [20]. In accordance, the inhibition of enhanced autophagy by TTCC blockers reduce tumor aggressiveness in recurrent Vemurafenib-resistant melanomas, decrease Cav3.1 expression, and avoid the acquisition of resistance to BRAFi treatment in $\mathrm{BRAF}^{\mathrm{V} 600 \mathrm{E}}$-mutant melanoma cells $[22,93]$. For all described, TTCC blockers could be targetable to deregulate autophagy and may offer a new mechanism to combat melanoma progression and therapeutic resistance to conventional anticancer drugs. 


\section{Conclusions}

TTCC blockers reduce the viability and tumor growth of melanoma cells, providing a new target therapy for melanoma treatment. Identifying an enhanced TTCC expression in melanoma and characterizing their function may introduce additional treatment alternatives, especially for patients who do not respond to standard therapies or develop resistant tumors. The expression of Cav3.1, with a positive correlation with autophagy biomarkers related to melanoma progression, prognosis, and resistance acquisition to $B R A F i$, can lead to the development of new therapeutic strategies by which TTCCs are blocked in order to deal with the development and emergence of metastatic melanoma. Thus, new biochemical compounds that block TTCCs could become valuable partners to impede midand long-term melanoma progression.

Author Contributions: C.B., P.S., O.M., I.d.I.R., R.M.M. and A.M. contributed equally to this manuscript. All authors have read and agreed to the published version of the manuscript.

Funding: This work was supported by grants from ISCIII/FEDER “Una manera de hacer Europa” (PI1500711 to RMM; PI18/00573 to RMM and AM). CB and PS hold a pre-doctoral fellowship from UdL-IRBLleida. RI holds a pre-doctoral fellowship from Asociación Española Contra el Cancer (AECC), Catalunya Contra el Cancer, Lleida. AM holds a post-doctoral fellowship from Asociación Española Contra el Cancer (AECC).

Conflicts of Interest: The authors declare no conflict of interest.

\section{References}

1. Monteith, G.R.; McAndrew, D.; Faddy, H.M.; Roberts-Thomson, S.J. Calcium and cancer: Targeting Ca ${ }^{2+}$ transport. Nat. Rev. Cancer 2007, 7, 519-530. [CrossRef] [PubMed]

2. Monteith, G.R.; Davis, F.M.; Roberts-Thomson, S.J. Calcium channels and pumps in cancer: Changes and consequences. J. Biol. Chem. 2012, 287, 31666-31673. [CrossRef] [PubMed]

3. Macià, A.; Herreros, J.; Martí, R.M.; Cantí, C. Calcium channel expression and applicability as targeted therapies in melanoma. Biomed Res. Int. 2015, 2015, e587135. [CrossRef] [PubMed]

4. Buchanan, P.J.; McCloskey, K.D. CaV channels and cancer: Canonical functions indicate benefits of repurposed drugs as cancer therapeutics. Eur. Biophys. J. 2016, 45, 621-633. [CrossRef]

5. Déliot, N.; Constantin, B. Plasma membrane calcium channels in cancer: Alterations and consequences for cell proliferation and migration. Biochim. Biophys. Acta 2015, 1848, 2512-2522. [CrossRef]

6. Hogan, P.G.; Rao, A. Store-operated calcium entry: Mechanisms and modulation. Biochem. Biophys. Res. Commun. 2015, 460, 40-49. [CrossRef]

7. Gurkoff, G.; Shahlaie, K.; Lyeth, B.; Berman, R. Voltage-gated calcium channel antagonists and traumatic brain injury. Pharmaceuticals 2013, 6, 788-812. [CrossRef]

8. Catterall, W.A. Structure and Regulation of Voltage-Gated Ca 2+ Channels. Annu. Rev. Cell Dev. Biol. 2000, 16, 521-555. [CrossRef]

9. Dolphin, A.C. Voltage-gated calcium channels and their auxiliary subunits: Physiology and pathophysiology and pharmacology. J. Physiol. 2016, 594, 5369-5390. [CrossRef]

10. Bhargava, A.; Saha, S. T-Type voltage gated calcium channels: A target in breast cancer? Breast Cancer Res. Treat. 2019, 173, 11-21. [CrossRef]

11. Kang, M.G.; Chen, C.C.; Felix, R.; Letts, V.A.; Frankel, W.N.; Mori, Y.; Campbell, K.P. Biochemical and biophysical evidence for gamma 2 subunit association with neuronal voltage-activated Ca2+ channels. J. Biol. Chem. 2001, 276, 32917-32924. [CrossRef] [PubMed]

12. Rousset, M.; Cens, T.; Restituito, S.; Barrere, C.; Black, J.L.; McEnery, M.W.; Charnet, P. Functional roles of gamma2, gamma3 and gamma4, three new Ca2+ channel subunits, in P/Q-type Ca2+ channel expressed in Xenopus oocytes. J. Physiol. 2001, 532, 583-593. [CrossRef]

13. Chen, R.-S.; Deng, T.-C.; Garcia, T.; Sellers, Z.M.; Best, P.M. Calcium channel gamma subunits: A functionally diverse protein family. Cell Biochem. Biophys. 2007, 47, 178-186. [CrossRef] [PubMed]

14. Antal, L.; Martin-Caraballo, M. T-type calcium channels in cancer. Cancers 2019, 11, 134. [CrossRef]

15. Perez-Reyes, E. Molecular physiology of low-voltage-activated T-type calcium channels. Physiol. Rev. 2003, 83, 117-161. [CrossRef] 
16. Senatore, A.; Guan, W.; Spafford, J.D. Cav3 T-type channels: Regulators for gating, membrane expression, and cation selectivity. Pflugers Arch. 2014, 466, 645-660. [CrossRef]

17. Huc, S.; Monteil, A.; Bidaud, I.; Barbara, G.; Chemin, J.; Lory, P. Regulation of T-type calcium channels: Signalling pathways and functional implications. Biochim. Biophys. Acta-Mol. Cell Res. 2009, 1793, 947-952. [CrossRef]

18. Das, A.; Pushparaj, C.; Bahí, N.; Sorolla, A.; Herreros, J.; Pamplona, R.; Vilella, R.; Matias-Guiu, X.; Martí, R.M.; Cantí, C. Functional expression of voltage-gated calcium channels in human melanoma. Pigment Cell Melanoma Res. 2012, 25, 200-212. [CrossRef]

19. Das, A.; Pushparaj, C.; Herreros, J.; Nager, M.; Vilella, R.; Portero, M.; Pamplona, R.; Matias-Guiu, X.; Martí, R.M.; Cantí, C. T-type calcium channel blockers inhibit autophagy and promote apoptosis of malignant melanoma cells. Pigment Cell Melanoma Res. 2013, 26, 874-885. [CrossRef]

20. Maiques, O.; Barceló, C.; Panosa, A.; Pijuan, J.; Orgaz, J.L.; Rodriguez-Hernandez, I.; Matas-Nadal, C.; Tell, G.; Vilella, R.; Fabra, A.; et al. T-type calcium channels drive migration/invasion in BRAFV600E melanoma cells through Snail1. Pigment Cell Melanoma Res. 2018, 31, 484-495. [CrossRef]

21. Maiques, O.; Macià, A.; Moreno, S.; Barceló, C.; Santacana, M.; Vea, A.; Herreros, J.; Gatius, S.; Ortega, E.; Valls, J.; et al. Immunohistochemical analysis of T-type calcium channels in acquired melanocytic naevi and melanoma. Br. J. Dermatol. 2017, 176, 1247-1258. [CrossRef] [PubMed]

22. Barceló, C.; Sisó, P.; Maiques, O.; García-Mulero, S.; Sanz-Pamplona, R.; Navaridas, R.; Megino, C.; Felip, I.; Urdanibia, I.; Eritja, N.; et al. T-Type calcium channels are a novel therapeutic target in Vemurafenib-resistant BRAFV600E melanoma. J. Investig. Dermatol. 2019, in press.

23. Phan, N.N.; Wang, C.Y.; Chen, C.F.; Sun, Z.; Lai, M.D.; Lin, Y.C. Voltage-gated calcium channels: Novel targets for cancer therapy. Oncol. Lett. 2017, 14, 2059-2074. [CrossRef] [PubMed]

24. Taylor, J.T.; Zeng, X.B.; Pottle, J.E.; Lee, K.; Wang, A.R.; Yi, S.G.; Scruggs, J.A.S.; Sikka, S.S.; Li, M. Calcium signaling and T-type calcium channels in cancer cell cycling. World J. Gastroenterol. 2008, 14, e4984. [CrossRef]

25. Dziegielewska, B.; Gray, L.S.; Dziegielewski, J. T-type calcium channels blockers as new tools in cancer therapies. Pflugers Arch. Eur. J. Physiol. 2014, 466, 801-810. [CrossRef] [PubMed]

26. Díaz-Lezama, N.; Hernández-Elvira, M.; Sandoval, A.; Monroy, A.; Felix, R.; Monjaraz, E. Ghrelin inhibits proliferation and increases T-type Ca2+ channel expression in PC-3 human prostate carcinoma cells. Biochem. Biophys. Res. Commun. 2010, 403, 24-29. [CrossRef]

27. Gackière, F.; Warnier, M.; Katsogiannou, M.; Derouiche, S.; Delcourt, P.; Dewailly, E.; Slomianny, C.; Humez, S.; Prevarskaya, N.; Roudbaraki, M.; et al. Functional coupling between large-conductance potassium channels and Cav3.2 voltage-dependent calcium channels participates in prostate cancer cell growth. Biol. Open 2013, 2, 941-951. [CrossRef]

28. Ohkubo, T.; Yamazaki, J. T-type voltage-activated calcium channel Ca v3.1, but not Ca v3.2, is involved in the inhibition of proliferation and apoptosis in MCF-7 human breast cancer cells. Int. J. Oncol. 2012, 41, 267-275.

29. Bertolesi, G.E.; Shi, C.; Elbaum, L.; Jollimore, C.; Rozenberg, G.; Barnes, S.; Kelly, M.E.M. The Ca(2+) channel antagonists mibefradil and pimozide inhibit cell growth via different cytotoxic mechanisms. Mol. Pharmacol. 2002, 62, 210-219. [CrossRef]

30. Taylor, J.T.; Huang, L.; Pottle, J.E.; Liu, K.; Yang, Y.; Zeng, X.; Keyser, B.M.; Agrawal, K.C.; Hansen, J.B.; Li, M. Selective blockade of T-type Ca2+ channels suppresses human breast cancer cell proliferation. Cancer Lett. 2008, 267, 116-124. [CrossRef]

31. Li, W.; Zhang, S.L.; Wang, N.; Zhang, B.B.; Li, M. Blockade of T-type Ca2+ channels inhibits human ovarian cancer cell proliferation. Cancer Investig. 2011, 29, 339-346. [CrossRef] [PubMed]

32. Dziegielewska, B.; Casarez, E.V.; Yang, W.Z.; Gray, L.S.; Dziegielewski, J.; Slack-Davis, J.K. T-Type Ca2+ Channel Inhibition Sensitizes Ovarian Cancer to Carboplatin. Mol. Cancer Ther. 2016, 15, 460-470. [CrossRef] [PubMed]

33. Dziegielewska, B.; Brautigan, D.L.; Larner, J.M.; Dziegielewski, J. T-type Ca2+ channel inhibition induces p53-dependent cell growth arrest and apoptosis through activation of p38-MAPK in colon cancer cells. Mol. Cancer Res. 2014, 12, 348-358. [CrossRef]

34. Lu, F.; Chen, H.; Zhou, C.; Liu, S.; Guo, M.; Chen, P.; Zhuang, H.; Xie, D.; Wu, S. T-type Ca2+ channel expression in human esophageal carcinomas: A functional role in proliferation. Cell Calcium 2008, 43, 49-58. [CrossRef] 
35. Valerie, N.C.K.; Dziegielewska, B.; Hosing, A.S.; Augustin, E.; Gray, L.S.; Brautigan, D.L.; Larner, J.M.; Dziegielewski, J. Inhibition of T-type calcium channels disrupts Akt signaling and promotes apoptosis in glioblastoma cells. Biochem. Pharmacol. 2013, 85, 888-897. [CrossRef]

36. Li, Y.; Liu, S.; Lu, F.; Zhang, T.; Chen, H.; Wu, S.; Zhuang, H. A role of functional T-type Ca2+ channel in hepatocellular carcinoma cell proliferation. Oncol. Rep. 2009, 22, 1229-1235.

37. Ueki, T.; Toyota, M.; Sohn, T.; Yeo, C.J.; Issa, J.P.; Hruban, R.H.; Goggins, M. Hypermethylation of multiple genes in pancreatic adenocarcinoma. Cancer Res. 2000, 60, 1835-1839.

38. Shen, L.; Ahuja, N.; Shen, Y.; Habib, N.A.; Toyota, M.; Rashid, A.; Issa, J.-P.J. DNA methylation and environmental exposures in human hepatocellular carcinoma. J. Natl. Cancer Inst. 2002, 94, 755-761. [CrossRef]

39. Toyota, M.; Ho, C.; Ohe-Toyota, M.; Baylin, S.B.; Issa, J.P. Inactivation of CACNA1G, a T-type calcium channel gene, by aberrant methylation of its 5' CpG island in human tumors. Cancer Res. 1999, 59, 4535-4541.

40. Ouadid-Ahidouch, H.; Rodat-Despoix, L.; Matifat, F.; Morin, G.; Ahidouch, A. DNA methylation of channel-related genes in cancers. Biochim. Biophys. Acta 2015, 1848, 2621-2628. [CrossRef]

41. Weatherhead, S.C.; Haniffa, M.; Lawrence, C.M. Melanomas arising from naevi and de novo melanomas-Does origin matter? Br. J. Dermatol. 2007, 156, 72-76. [CrossRef]

42. Lee, J.S.; DuBois, S.G.; Coccia, P.F.; Bleyer, A.; Olin, R.L.; Goldsby, R.E. Increased risk of second malignant neoplasms in adolescents and young adults with cancer. Cancer 2016, 122, 116-123. [CrossRef]

43. Ríos, L.; Nagore, E.; López, J.L.; Redondo, P.; Martí, R.M.; Fernández-de-Misa, R.; Soler, B. Melanoma Characteristics at Diagnosis From The Spanish National Cutaneous Melanoma Registry: 15 Years of Experience. Actas Dermo-Sifiliográficas (Engl. Ed.) 2013, 104, 789-799.

44. Ekwueme, D.U.; Guy, G.P.; Li, C.; Rim, S.H.; Parelkar, P.; Chen, S.C. The health burden and economic costs of cutaneous melanoma mortality by race/ethnicity-United States, 2000 to 2006. J. Am. Acad. Dermatol. 2011, 65, e1-e12. [CrossRef] [PubMed]

45. Gray-Schopfer, V.; Wellbrock, C.; Marais, R. Melanoma biology and new targeted therapy. Nature 2007, 445, 851-857. [CrossRef] [PubMed]

46. Sarkisian, S.; Nair, S.; Sharma, R. Current Clinical Trials in the Treatment of Advanced Melanomas. Surg. Clin. N. Am. 2020, 100, 201-208. [CrossRef]

47. Cox, J.L.; Lancaster, T.; Carlson, C.G. Changes in the motility of B16F10 melanoma cells induced by alterations in resting calcium influx. Melanoma Res. 2002, 12, 211-219. [CrossRef]

48. Deli, T.; Varga, N.; Adám, A.; Kenessey, I.; Rásó, E.; Puskás, L.G.; Tóvári, J.; Fodor, J.; Fehér, M.; Szigeti, G.P.; et al. Functional genomics of calcium channels in human melanoma cells. Int. J. Cancer 2007, 121, 55-65. [CrossRef]

49. Sensi, M.; Nicolini, G.; Petti, C.; Bersani, I.; Lozupone, F.; Molla, A.; Vegetti, C.; Nonaka, D.; Mortarini, R.; Parmiani, G.; et al. Mutually exclusive NRASQ61R and BRAFV600E mutations at the single-cell level in the same human melanoma. Oncogene 2006, 25, 3357-3364. [CrossRef]

50. Ertel, S.I.; Clozel, J.P. Mibefradil (Ro 40-5967): The first selective T-type Ca2+ channel blocker. Expert Opin. Investig. Drugs 1997, 6, 569-582. [CrossRef]

51. Chen, J.J.; Cai, N.; Chen, G.Z.; Jia, C.C.; Qiu, D.B.; Du, C.; Liu, W.; Yang, Y.; Long, Z.J.; Zhang, Q. The neuroleptic drug pimozide inhibits stem-like cell maintenance and tumorigenicity in hepatocellular carcinoma. Oncotarget 2017, 8, 17593-17609. [CrossRef]

52. Zhou, C.K.; Check, D.P.; Lortet-Tieulent, J.; Laversanne, M.; Jemal, A.; Ferlay, J.; Bray, F.; Cook, M.B.; Devesa, S.S. Prostate cancer incidence in 43 populations worldwide: An analysis of time trends overall and by age group. Int. J. Cancer 2016, 138, 1388-1400. [CrossRef]

53. Johnston, A.N.; Bu, W.; Hein, S.; Garcia, S.; Camacho, L.; Xue, L.; Qin, L.; Nagi, C.; Hilsenbeck, S.G.; Kapali, J.; et al. Hyperprolactinemia-inducing antipsychotics increase breast cancer risk by activating JAK-STAT5 in precancerous lesions. Breast Cancer Res. 2018, 20, e42. [CrossRef]

54. Jia, H.; Ren, W.; Feng, Y.; Wei, T.; Guo, M.; Guo, J.; Zhao, J.; Song, X.; Wang, M.; Zhao, T.; et al. The enhanced antitumour response of pimozide combined with the IDO inhibitor L-MT in melanoma. Int. J. Oncol. 2018, 53, 949-960. [CrossRef]

55. Ma, X.H.; Piao, S.; Wang, D.; Mcafee, Q.W.; Nathanson, K.L.; Lum, J.J.; Li, L.Z.; Amaravadi, R.K. Measurements of tumor cell autophagy predict invasiveness, resistance to chemotherapy, and survival in melanoma. Clin. Cancer Res. 2011, 17, 3478-3489. [CrossRef] 
56. Corazzari, M.; Rapino, F.; Ciccosanti, F.; Giglio, P.; Antonioli, M.; Conti, B.; Fimia, G.M.; Lovat, P.E.; Piacentini, M. Oncogenic BRAF induces chronic ER stress condition resulting in increased basal autophagy and apoptotic resistance of cutaneous melanoma. Cell Death Differ. 2015, 22, 946-958. [CrossRef]

57. Rossier, M.F. T channels and steroid biosynthesis: In search of a link with mitochondria. Cell Calcium 2006, 40, 155-164. [CrossRef]

58. Yang, Z.J.; Chee, C.E.; Huang, S.; Sinicrope, F.A. The role of autophagy in cancer: Therapeutic implications. Mol. Cancer Ther. 2011, 10, 1533-1541. [CrossRef]

59. Filippi-Chiela, E.C.; Viegas, M.S.; Thomé, M.P.; Buffon, A.; Wink, M.R.; Lenz, G. Modulation of Autophagy by Calcium Signalosome in Human Disease. Mol. Pharmacol. 2016, 90, 371-384. [CrossRef]

60. Xie, X.; Koh, J.Y.; Price, S.; White, E.; Mehnert, J.M. Atg7 Overcomes Senescence and Promotes Growth of BrafV600E-Driven Melanoma. Cancer Discov. 2015, 5, 410-423. [CrossRef]

61. Sharifi, M.N.; Mowers, E.E.; Drake, L.E.; Collier, C.; Chen, H.; Zamora, M.; Mui, S.; Macleod, K.F. Autophagy Promotes Focal Adhesion Disassembly and Cell Motility of Metastatic Tumor Cells through the Direct Interaction of Paxillin with LC3. Cell Rep. 2016, 15, 1660-1672. [CrossRef] [PubMed]

62. Rimessi, A.; Bonora, M.; Marchi, S.; Patergnani, S.; Marobbio, C.M.; Lasorsa, F.M.; Pinton, P. Perturbed mitochondrial Ca 2+ signals as causes or consequences of mitophagy induction. Autophagy 2013, 9, 1677-1686. [CrossRef] [PubMed]

63. Gouriou, Y.; Bijlenga, P.; Demaurex, N. Mitochondrial Ca2+ uptake from plasma membrane Cav3.2 protein channels contributes to ischemic toxicity in PC12 cells. J. Biol. Chem. 2013, 288, 12459-12468. [CrossRef] [PubMed]

64. Wilkinson, S. Emerging Principles of Selective ER Autophagy. J. Mol. Biol. 2020, 432, 185-205. [CrossRef] [PubMed]

65. Bahar, E.; Kim, H.; Yoon, H. ER stress-mediated signaling: Action potential and Ca2+ as key players. Int. J. Mol. Sci. 2016, 17, 1558. [CrossRef] [PubMed]

66. Pijuan, J.; Barceló, C.; Moreno, D.F.; Maiques, O.; Sisó, P.; Marti, R.M.; Macià, A.; Panosa, A. In vitro cell migration, invasion, and adhesion assays: From cell imaging to data analysis. Front. Cell Dev. Biol. 2019, 7, e107. [CrossRef]

67. Chin, L.; Garraway, L.A.; Fisher, D.E. Malignant melanoma: Genetics and therapeutics in the genomic era. Genes Dev. 2006, 20, 2149-2182. [CrossRef]

68. Fazilaty, H.; Rago, L.; Kass Youssef, K.; Ocaña, O.H.; Garcia-Asencio, F.; Arcas, A.; Galceran, J.; Nieto, M.A. A gene regulatory network to control EMT programs in development and disease. Nat. Commun. 2019, 10, 1-16. [CrossRef]

69. Hao, L.; Ha, J.R.; Kuzel, P.; Garcia, E.; Persad, S. Cadherin switch from E- to N-cadherin in melanoma progression is regulated by the PI3K/PTEN pathway through Twist and Snail. Br. J. Dermatol. 2012, 166, 1184-1197. [CrossRef]

70. Olmeda, D.; Jordá, M.; Peinado, H.; Fabra, A.; Cano, A. Snail silencing effectively suppresses tumour growth and invasiveness. Oncogene 2007, 26, 1862-1874. [CrossRef]

71. Ascierto, P.A.; Kirkwood, J.M.; Grob, J.J.; Simeone, E.; Grimaldi, A.M.; Maio, M.; Palmieri, G.; Testori, A.; Marincola, F.M.; Mozzillo, N. The role of BRAF V600 mutation in melanoma. J. Transl. Med. 2012, 10, e85. [CrossRef] [PubMed]

72. Winder, M.; Virós, A. Mechanisms of Drug Resistance in Melanoma. Handb. Exp. Pharmacol. 2017, 249, 91-108.

73. Kozar, I.; Margue, C.; Rothengatter, S.; Haan, C.; Kreis, S. Many ways to resistance: How melanoma cells evade targeted therapies. Biochim. Biophys. Acta - Rev. Cancer 2019, 1871, 313-322. [CrossRef] [PubMed]

74. Kong, X.; Kuilman, T.; Shahrabi, A.; Boshuizen, J.; Kemper, K.; Song, J.Y.; Niessen, H.W.M.; Rozeman, E.A.; Foppen, M.H.G.; Blank, C.U.; et al. Cancer drug addiction is relayed by an ERK2-dependent phenotype switch. Nature 2017, 550, 270-274. [CrossRef]

75. Baenke, F.; Chaneton, B.; Smith, M.; Van Den Broek, N.; Hogan, K.; Tang, H.; Viros, A.; Martin, M.; Galbraith, L.; Girotti, M.R.; et al. Resistance to BRAF inhibitors induces glutamine dependency in melanoma cells. Mol. Oncol. 2016, 10, 73-84. [CrossRef]

76. Su, Y.; Wei, W.; Robert, L.; Xue, M.; Tsoi, J.; Garcia-Diaz, A.; Homet Moreno, B.; Kim, J.; Ng, R.H.; Lee, J.W.; et al. Single-cell analysis resolves the cell state transition and signaling dynamics associated with melanoma drug-induced resistance. Proc. Natl. Acad. Sci. USA 2017, 114, 13679-13684. [CrossRef] 
77. Amann, V.C.; Hoffmann, D.; Mangana, J.; Dummer, R.; Goldinger, S.M. Successful retreatment with combined BRAF/MEK inhibition in metastatic BRAFV600-mutated melanoma. J. Eur. Acad. Dermatol. Venereol. 2017, 31, 1638-1640. [CrossRef]

78. Manzano, J.L.; Layos, L.; Bugés, C.; de Los Llanos Gil, M.; Vila, L.; Martínez-Balibrea, E.; Martínez-Cardús, A. Resistant mechanisms to BRAF inhibitors in melanoma. Ann. Transl. Med. 2016, 4, e237. [CrossRef]

79. Muñoz-Couselo, E.; Adelantado, E.Z.; Ortiz, C.; García, J.S.; Perez-Garcia, J. NRAS-mutant melanoma: Current challenges and future prospect. Onco. Targets Ther. 2017, 10, 3941-3947.

80. Kischel, P.; Girault, A.; Rodat-Despoix, L.; Chamlali, M.; Radoslavova, S.; Daya, H.A.; Lefebvre, T.; Foulon, A.; Rybarczyk, P.; Hague, F.; et al. Ion channels: New actors playing in chemotherapeutic resistance. Cancers 2019, 11, 376. [CrossRef]

81. Ma, X.-H.; Piao, S.-F.; Dey, S.; McAfee, Q.; Karakousis, G.; Villanueva, J.; Hart, L.S.; Levi, S.; Hu, J.; Zhang, G.; et al. Targeting ER stress-induced autophagy overcomes BRAF inhibitor resistance in melanoma. J. Clin. Investig. 2014, 124, 1406-1417. [CrossRef]

82. Martin, S.; Dudek-Perić, A.M.; Maes, H.; Garg, A.D.; Gabrysiak, M.; Demirsoy, S.; Swinnen, J.V.; Agostinis, P. Concurrent MEK and autophagy inhibition is required to restore cell death associated danger-signalling in Vemurafenib-resistant melanoma cells. Biochem. Pharmacol. 2015, 93, 290-304. [CrossRef]

83. Martin, S.; Dudek-Peric, A.M.; Garg, A.D.; Roose, H.; Demirsoy, S.; Van Eygen, S.; Mertens, F.; Vangheluwe, P.; Vankelecom, H.; Agostinis, P. An autophagy-driven pathway of ATP secretion supports the aggressive phenotype of BRAFV600E inhibitor-resistant metastatic melanoma cells. Autophagy 2017, 13, 1512-1527. [CrossRef] [PubMed]

84. Santoni, G.; Santoni, M.; Nabissi, M. Functional role of T-type calcium channels in tumour growth and progression: Prospective in cancer therapy. Br. J. Pharmacol. 2012, 166, 1244-1246. [CrossRef] [PubMed]

85. Zhang, Y.; Cruickshanks, N.; Yuan, F.; Wang, B.; Pahuski, M.; Wulfkuhle, J.; Gallagher, I.; Koeppel, A.F.; Hatef, S.; Papanicolas, C.; et al. Targetable T-type calcium channels drive glioblastoma. Cancer Res. 2017, 77, 3479-3490. [CrossRef] [PubMed]

86. Sheehan, J.P.; Xu, Z.; Popp, B.; Kowalski, L.; Schlesinger, D. Inhibition of glioblastoma and enhancement of survival via the use of mibefradil in conjunction with radiosurgery. J. Neurosurg. 2013, 118, 830-837. [CrossRef]

87. Lijnen, P.; Fagard, R.; Petrov, V. Mibefradil-induced inhibition of proliferation of human peripheral blood mononuclear cells. J. Cardiovasc. Pharmacol. 1999, 33, 595-604. [CrossRef]

88. Schmitt, R.; Kleinbloesem, C.H.; Belz, G.G.; Schroeter, V.; Feifel, U.; Pozenel, H.; Kirch, W.; Halabi, A.; Woittiez, A.J.; Welker, H.A. Hemodynamic and humoral effects of the novel calcium antagonist Ro 40-5967 in patients with hypertension. Clin. Pharmacol. Ther. 1992, 52, 314-323. [CrossRef]

89. Chemin, J.; Monteil, A.; Perez-Reyes, E.; Nargeot, J.; Lory, P. Direct inhibition of T-type calcium channels by the endogenous cannabinoid anandamide. EMBO J. 2001, 20, 7033-7040. [CrossRef]

90. Hirooka, K.; Bertolesi, G.E.; Kelly, M.E.M.; Denovan-Wright, E.M.; Sun, X.; Hamid, J.; Zamponi, G.W.; Juhasz, A.E.; Haynes, L.W.; Barnes, S. T-type calcium channel $\alpha 1 \mathrm{G}$ and $\alpha 1 \mathrm{H}$ subunits in human retinoblastoma cells and their loss after differentiation. J. Neurophysiol. 2002, 88, 196-205. [CrossRef]

91. Rodrigues, A.L.; Brescia, M.; Kolshinski, A.; Moreira, T.H.; Cameron, R.; Bailley, G.; Beirão, P.S.L.; Zaccollo, M.; Cruz, J.S. Increase in Ca2 + current by sustained cAMP levels enhances proliferation rate in GH3 cells. Life Sci. 2018, 192, 144-150. [CrossRef] [PubMed]

92. Huang, J.-B.; Kindzelskii, A.L.; Clark, A.J.; Petty, H.R. Identification of channels promoting calcium spikes and waves in HT1080 tumor cells: Their apparent roles in cell motility and invasion. Cancer Res. 2004, 64, 2482-2489. [CrossRef]

93. Büsselberg, D.; Florea, A.M. Targeting intracellular calcium signaling ([Ca2+]i) to overcome acquired multidrug resistance of cancer cells: A mini-overview. Cancers 2017, 9, 48.

(C) 2020 by the authors. Licensee MDPI, Basel, Switzerland. This article is an open access article distributed under the terms and conditions of the Creative Commons Attribution (CC BY) license (http://creativecommons.org/licenses/by/4.0/). 